\title{
The neoclassical sink and the heterodox spiral: political divides and lines of communication in economics
}

\author{
Gary A. Dymski* \\ Leeds University Business School, University of Leeds, UK and Department of Economics, University of \\ California, Riverside, USA
}

A crisis that started as a textbook case of how financial and asset markets can spin out of control without adequate public oversight has transmuted in 5 years into a crisis of irresponsible sovereigns, such that restoring prosperity requires that governments re-establish control over their own excessive spending. How did this happen? This paper explains the recovery of position by pro-market, restricted-government proponents in economics on the basis of political divides and segmented lines of communication within the academic economics profession. These political divides involve a double invisibilization of power within economics: an invisibilization both of the political purposes served by a profession whose leading models deny the relevance of social and political power, and of the ideational barriers to entry into 'mainstream' departments. The argument is motivated and illustrated by the cases of the subprime and the eurozone crises.

Keywords: eurozone crisis, subprime crisis, neoclassical and heterodox approaches to economics, power, political divide

JEL codes: $B 41, B 50, G 21, H 12, N 33, P 16$

\section{INTRODUCTION}

The global financial crisis, when it first emerged in 2007-2008, appeared to be a silver bullet aimed at the heart of economists' belief in self-regulating markets and their suspicion of government regulation. But 5 years later, austerity economic policies have been widely adopted in response to a crisis of the eurozone. So a crisis that started as a textbook case of how financial and asset markets can spin out of control without adequate public oversight has transmuted in 5 years into a crisis of irresponsible sovereigns, such that restoring prosperity requires that governments re-establish control over their own excessive spending. The relevance of Hyman Minsky's celebrated ideas about financial instability for the subprime crisis were acknowledged (Cassidy 2009); but the many Minsky dimensions of the European crisis have largely been unrecognized.

* g.dymski@leeds.ac.uk. This paper builds on the ideas set forth in Dymski (2013a). Some portions remain as in the earlier essay, but the core arguments made here are distinct from those developed there. The author gratefully acknowledges the insightful comments of an anonymous referee, which substantially improved the arguments presented here. All remaining errors are the author's responsibility. 
This paper explains this recovery of position by pro-market, restricted-government proponents in economics on the basis of political divides and segmented lines of communication within the academic economics profession. These political divides involve a double invisibilization of power within economics: an invisibilization both of the political purposes served by a profession whose leading models deny the relevance of social and political power, and of the ideational barriers to entry into 'mainstream' departments.

We make this argument by contrasting two admittedly oversimplified perspectives that serve as fundamental reference points for those engaged in the labor of developing, transmitting, and refining economic explanations of events in the real world and what can be done about them using policy tools. On one side are economists who work from neoclassical premises, and on the other are those rooted in heterodox analysis. There is little real dialogue between these two approaches to economic explanation. Those starting from heterodox premises emphasize the importance and multi-dimensional character of social power in profound economic crises. But economists working from neoclassical premises view explanations as unsatisfactory when they emphasize the centrality of power and of complex interlinkages. When we factor in the asymmetric lines of communication within the discipline, the disconnect between those who see economic outcomes as reflecting power-laden, irreducibly complex dynamics and those who see these outcomes as manifestations of mechanism failure is virtually complete. Some economists seek explanations that renew the explanatory relevance of the competitive-market ideal, while others see the necessity of describing a social world that is ever further away from that ideal.

Section 2 elaborates on the definitions of the terms 'neoclassical' and 'heterodox' as used here, and explains why neoclassical economics explanations can be viewed as operating as a sink, while heterodox explanations take the form of a spiral. Section 3 briefly summarizes the subprime crisis, and section 4 elaborates on the disjunctures in economists' views of it. Section 5 turns to the eurozone crisis; Section 6 summarizes the argument and concludes.

\section{NEOCLASSICAL AND HETERODOX ECONOMICS: SINK AND SPIRAL}

We can differentiate three perspectives that inform much of contemporary economics: neoliberal, neoclassical, and heterodox. The neoliberal entry-point in economics builds on the view that market outcomes will be optimal when economic agents make rational choices with minimal government interference. Neoclassical economics accepts the premise that analysing rational choice in individual or representative markets provides a sufficient basis for virtually all problems involving the allocation of resources in society. The two are related, but not identical: neoclassical analysis can be used to demonstrate welfare-improving government interventions. That said, autarchic market outcomes always remain the basic analytical reference point; and the development of neoclassical economics - even the replacement of the term 'political economy' with 'economics' - served the class interest of those who held power over capital (de Vroey 1975). The fact that the neoclassical framework sidelined attention to distribution and power was no coincidence.

By contrast, the identifying core of heterodox economics is the view that capitalism cannot be even approximately described by an autarchic equilibrium model of market processes. Instead, capitalism is necessarily defined by its destabilizing tendencies. The source of destabilization was defined, is variously defined: for some, it arises because 
social power overspills the boundaries of economic relationships; for others, fundamental uncertainty can have this effect; for others still, class-based, gender-based, or racial/ethnic inequality can have this effect as well. ${ }^{1}$ In the heterodox perspective, social and economic processes interpenetrate; individual choice may be viewed as constrained by social conventions and systemic patterns of resource inequality. ${ }^{2}$

While economists working with heterodox premises usually emphasize one destabilizing tendency in their analysis (uncertainty or gender, but seldom both), an important sociological fact about contemporary economics is that those working primarily with any one heterodox driver are likely to acknowledge that other drivers are significant as well in overall capitalist dynamics. ${ }^{3}$ This is not to say that economists working from neoclassical premises all agree on the disturbances that push economies away from optimal equilibria; they do not. But they do agree that an equilibrium constitutes the appropriate reference point (and return point) for economic analysis. ${ }^{4}$ The line between the social and the economic is well-marked; and when a social condition transgresses it, one can try to identify an economic mechanism that can re-establish the separation. For heterodox economists who acknowledge the inextricable interlinkage of the social and economic, the line between the two blurs. So it would be a contradiction to contend that resolving one dimension in which the social infects economic outcomes - say, gender inequality - would be sufficient to restore economic dynamics freed of interaction with social factors. For this is to assert: 'remove this one problem, and a stable equilibrium becomes feasible under capitalism. ${ }^{5}$ Naïve views of this type may once have characterized economic debates in an earlier day, but evidently are rare in an age that has absorbed the implications of non-linearity and complexity in social systems, and that has seen a flourishing of new social movements.

This is not to say that economists working from neoclassical premises have no curiosity about social processes; to the contrary, their interest is growing. ${ }^{6}$ But this interest

1. This definition is a poor fit in the case of economists working with relatively precise models based on organizing principles other than on utility maximization. A case in point is Marxian value theory. While Marxian value theory encompasses a vision of self-undermining dynamics in capitalism, its relationship with social distinctions not based on class position is a much-debated topic: for some proponents, these other distinctions reduce to class position in the last instance; for others, as in the neoclassical vision, they are outside the boundaries of theoretical attention. A full discussion of this point would require separate treatment, and is not pursued further here.

2. Much post-Keynesian analysis emphasizes uncertainty. The problem of uncertainty in itself creates an irreducibly social dimension for economic processes, in that those affected by it necessarily adopt one or more social conventions as means of containing its impact.

3. This assertion draws on participant observation, not empirical data.

4. This statement, in effect, takes the side of Vernengo (2010) in his debate with Colander et al. (2004) over whether neoclassical economics has been undergoing a fundamental shift making it more open to free and full participation by economists working from heterodox premises.

5. It is understood that to introduce a given heterodox element - say, fundamental uncertainty into a model that is otherwise neoclassical, as an experiment, is one thing; to subscribe to the view that only this heterodox element can matter in economic outcomes, among any others that might be proposed, is quite another. Harcourt (2007) points out that one key root of the divergence of views of heterodox economists lies in the different non-equilibrium visions of Marx and Keynes about the contradictory nature of capitalist economies; to study these contrasting views is, in part, to see the multiplicity of valid entry points into the 'economic problem.'

6. 'Freakonomics' - 'the hidden side of everything' as Levitt and Dubner (2005) put it involves precisely the application of utility-maximization principles to diverse social situations. In any event, economists were 'social science imperialists' (in the phrase of Harcourt 1982) well before the 'freakonomics' craze. 
rests, in the main, in seeing to what extent rational-choice models augmented by distorting factors such as risk or transaction costs can explain social outcomes. When confronted with a situation of structural inequality so profound that rational-choice explanations are largely irrelevant, economists wishing to build rational-choice models must either model the irrelevant or abandon neoclassical premises. This is where we find one power line in economics. Academic economics departments have increasingly devalued case studies and detailed historical and institutional analysis in favor of theoretically integrated models. ${ }^{7}$ In most cases, these departments are structured as clubs, to which only those who have paid the membership fee (a doctorate in economics) and follow rules of decorum are admitted. And a centrally important rule is to develop explanations that conform with (or at least do not directly challenge) the postulate of rationality. This rule can be substituted by another, the expectation that one should publish consistently in leading academic journals, as conventionally defined. In this case, the power line is policed at a distance. Heterodox discourses have survived and even flourished. However, the spaces available for circulating, publishing, and testing heterodox ideas exist largely outside of the academic venues for neoclassical research.

This power line within the discipline, then, largely separates those whose explorations of the social-economic interface often lead them to bring discussions of social power into economic discourse, from those who prefer to identify rigidities or incentive problems in market mechanisms. This divide, in turn, leads to strong asymmetries in lines of communication within economics. Economists working with neoclassical premises have numerous channels for exchanging ideas among themselves, and the same - less well resourced, in the main - is the case for economists working in heterodox traditions. There are, however, precious few opportunities for exchanges between those pursuing heterodox ideas and those pursuing neoclassical premises. Those that have occurred have often been one-off experiments. ${ }^{8}$

The development of ideas in reaction to new events operates very differently in neoclassical and heterodox economics. Neoclassical theory functions as an intellectual sink: ideas about market dynamics or real-world policy dilemmas are interpreted with reference to the premises held in common with other models using rational-choice, optimization-based analysis. At root, all ideas are understood (or not understood) relative to their distance from Walrasian general equilibrium.

Heterodox theory, by contrast, has the structure of clusters along a spiral: it contains a rich set of loosely-related but largely independent foci (gender, race, instability, uncertainty), each developing along one or more exploratory trajectories that intersect but always push deeper into historically and conceptually distinct intellectual ground. ${ }^{9}$ These interconnecting spirals unfold at an ever-greater distance from the abstract notion of an efficient equilibrium, and do not converge asymptotically to a shared, heterodox reduced-form model. So a specific challenge to one or another sub-stratum of heterodox theory - for example, a false claim that government reinvestment policy forced lenders to make home-mortgage loans to uncreditworthy minority borrowers, against their better judgment - will not send all other heterodox substrata up in arms.

7. Note the virtual disappearance of industrial economics in favor of the game-theoretic modeling of strategic choices in different market structures, as well as the reconfiguration of development economics as a cross between principal-agent theory and mechanism design.

8. Hyman Minsky organized several such experiments in his years at the Levy Economics Institute.

9. Geoff Harcourt has described the methodological diversity embodied in heterodox political economy as akin to 'horses for courses' (see, for example, Harcourt 1982, p. 388). 
We can illustrate this contrast by considering how institutions - from banks to currency unions - are understood when working from neoclassical and heterodox premises. The analytical starting point in neoclassical theory is a general equilibrium with perfect information, zero transaction costs, and agents with well-defined and rational utility functions and endowments. In such an equilibrium, no banks, no bank regulators, and no nation states are needed; agents can maximize their welfare given their endowments without any help. Of all the assumptions underpinning this autarchic paradise, those most commonly modified to create analytical space for institutions in neoclassical analysis are complete information and costless transactions. The key idea is that, for an institution to exist in an optimizing environment, it must have reduced deadweight losses that would otherwise be borne by the agents benefiting from it. So banks exist because there are economies of scale in monitoring the performance of borrowers who otherwise have incentives to cheat lenders (Diamond 1984). Currency unions, in turn, should be created when agents' prospective gain from their expected advantages (including the free intra-union movement of goods and capital) offset their expected costs (the loss of the capacity to reset the exchange rate with the rest of the world, for participating countries). This approach rules out the foundational Keynesian assumption that aggregate demand is independent from and not reducible to aggregate supply. In these models, any excess of expenditures over income in the short term must be compensated by a budget surplus in the longer term; in the end, every economic unit's budget constraint - individual and nation state - binds.

We elaborate only briefly here on a heterodox reaction to these sorts of theoretical constructions of phenomena such as banks or the eurozone. The notion that the existence of institutions in market contexts can be attributed in the first instance to agents' preferences would be treated as nonsensical. To rule out the presence and use of social power in the creation of institutions represents a denial both of common sense and of the opportunity to build a historically-grounded, institutionally appropriate representation of the institution in question.

This brings us to the link between the neoclassical sink, the heterodox spiral, and the eurozone crisis. For many neoclassical economists, the subprime meltdown shook their faith in market forces, but the eurozone crisis restored it. For heterodox economists, neoliberal ideas constituted a crucial precondition for both meltdowns. For those committed to neoclassical ideas, discourse revolves around the ideal of perfectly coordinated, decentralized markets, even when events suggest that this ideal is unattainable. ${ }^{10}$ Heterodox economists generally reject the constraints on thinking that are imposed by this intellectual sink. Because of the evolution of academic economics, proponents of neoclassical and heterodox ideas have precious little space for debating either the relevance of the efficient-market model or the reconstruction of financial regulation and macroeconomic policy. Those economists who are best positioned to provide novel insights into why such crises arise are generally poorly positioned to pose challenges to neoliberal claims that economists committed to neoclassical discourse must consider seriously.

So in a time that compels change, economics has not insulated itself against change because it has been captured by ideologues. Rather, its insulation results from a double bind: economists committed to neoclassical thinking equate changing their fundamental views with surrendering the basis of their professional identity (and the status that

10. Harcourt (2010) shows how the logical mistakes and descriptive errors in depicting economic dynamics have led systematically to a crisis in mainstream economics, which recent events have highlighted. 
accords them); those economists committed to heterodox ideas have few incentives and little ability to engage neoclassical ideas in such a debate, while being pulled intellectually farther away from economic theory, not back into debates about its conceptual core.

\section{NEOLIBERAL ECONOMICS TAKES A BULLET: THE SUBPRIME CRISIS}

Neoliberal ideas about financial regulation and economic policy have dominated US and global policy-making since the 1980s. During this neoliberal era, multinational firms with global reach have increased their control of production and distribution, and national governments' capacity to control the activities of economic agents operating within or across their borders has been increasingly constrained or even censured. ${ }^{11}$ The two aspects of neoliberalism are interlinked: firms that can threaten to relocate anywhere use the threat of withdrawal to force host governments to minimize their regulatory constraints and tax assessments. This is the very definition of power.

Governments in Latin America and Asia were put under duress and forced to open their markets by debt crises in the 1980s and 1990s. Some large financial intermediaries failed in these crises. But the financial conglomerates that survived became increasingly dominant, using their vast resources and access to global financial centers to extract fees from wealthy and poor alike. These conglomerates' products and services pervaded so many areas of economic life that the neoliberal era has been characterized as a period of financialization (Palley 2007).

So extensive were the threats made in this period by mobile financial capital, and so devastating the social ruin that followed international debt crises, that supra-national governance changed its character. No longer did international bodies define the parameters of permissible activity for private-market entities; instead, nation states created regional compacts whose aim was to render their member nations more attractive to globally mobile capital. Neoliberal mechanism designs (Dymski 2011b) such as the North American Free Trade Agreement aim not at using the expenditure-multiplier powers of expansionary public spending, but instead at preventing member states from overstepping fiscal boundaries. Since fiscal restraint attracts (scarce) foreign capital - and fiscal expansion deters it - fiscal restraint and competitiveness policies have replaced fiscal stimulus and public investment in neoliberal-era governments' toolkits.

In the US and UK, financial deregulation and improvements in IT technology opened the door to subprime lending. In both nations, many subprime mortgages were sold in the 1990s, especially in minority areas. As housing prices rose sharply upward in the 2000s, subprime loans spread to the broader market and sustained an increasingly frantic housing boom. Meanwhile, large financial firms were profiting not only from bundling and selling mortgages, but also from taking positions in derivatives markets based on the value of subprime securities. The housing market peaked in 2006, leading directly to the June 2007 failure of two Bear Stearns subprime funds, and the September 2007 meltdown of the UK's Northern Rock. The asset-backed commercial paper market then collapsed, forcing central banks to inject liquidity directly into the markets: the subprime crisis had arrived.

11. The now widely-acknowledged impact of multinational firms with oligopolistic power, including banks, is a vindication of the overlooked analyses of Kurt Rothschild (1947) and Steven Hymer (1972). For elaboration on these ideas, see Harcourt and Nolan (2009). 
A few economists saw a crisis coming: Shiller (2005), Roubini (2007), Baker (2007) and Kaufman (2007) warned that the housing bubble would burst. Krugman (2007a, 2007b) used his New York Times op-ed bully pulpit to warn that subprime lending would collapse and create profound social and financial damage. These warnings brought rejoinders. Downs (2007) and Calomiris (2007) argued that a subprime market meltdown would have very little effect on either housing markets or the economy as a whole. Think-tank economist Pollock (2007) pointed out that the subprime crisis is only the latest example of a boom-bust pattern that has characterized financial markets through history. By implication, interventions to offset losses are counterproductive. Meltzer (2007) encapsulated this view as follows in The Wall Street Journal: "Capitalism without failure is like religion without sin. The answer to excessive risktaking is "let "em fail." ... Bailouts encourage excessive risk-taking; failures encourage prudent risk taking.'

These skirmishes between economists were followed by a sequence of failures or takeovers of investment funds, brokers, and banks in the first 8 months of 2008, all handled by central-bank interventions. But when the web of unpayable debts and collapsing asset prices reached Shearson-Lehman Brothers, its super-leveraged, hidden positions in subprime-linked derivatives and collateralized debt obligations (CDOs) proved indigestible. No private-sector institution was large enough and healthy enough to buy it. With Lehman Brothers' failure in September 2008, the subprime crisis blossomed into a full-blown Wall Street meltdown.

Clearly, the subprime crisis was linked to the aggressive application of efficient financial markets perspectives to credit-market-based instruments that required far more forceful regulation. No economist had specifically advocated subprime lending coordinated by hyper-leveraged megabanks under the cover of moral-hazard-influenced credit ratings; but the academic literature provided the rationale for the view that these innovations in lending and risk-sharing reflected increasing efficiency in financial markets. ${ }^{12}$ Further, these institutional developments were consistent with the neoliberal view, widely held among financial economists, that market forces match risk-taking to risk-bearing better than a system orchestrated by public mandates and government guarantees. ${ }^{13}$

The last quarter of 2008 saw precipitous government action to protect the integrity of financial markets by extending too-big-to-fail protection to a privileged group of megabanks. The macroeconomy entered an extended period of recession and stagnation, accompanied by increasingly aggressive central-bank 'quantitative easing.' While policy failures caused by mistaken views in economic theory normally escape public attention, the subprime collapse was linked directly to extensive Wall Street use of formulas crafted by Nobel-Prize-winning economists. This prompted Nobel winner Kenneth Arrow (2008) to warn that the subprime crisis exposed the 'conflict between the genuine social value of increased variety and spread of risk-bearing securities and the limits imposed by the growing difficulty of understanding the underlying risks imposed by growing complexity.' Arrow's commentary was an early entry into what soon became a deluge of public reflections about whether economists had

12. Fama (1980) showed that unfettered financial markets can establish efficient lenderborrower linkages which regulated depositories are unable to influence. Fender and Mitchell (2005) and Oldfield (2000) analyse leveraged securitization.

13. One prominent example is the US Shadow Financial Regulatory Committee, founded in 1986 and still in operation. 
been seduced by their own models, misled by ideologues, or captured by special interests. ${ }^{14}$

Meanwhile, unfolding events called economists' reputation ever more profoundly into question. Two Congressional inquiries into the subprime crisis and the passage of financial reform legislation kept the spotlight on efficient financial-market theory. And when recession was followed by stagnation instead of robust growth, debate broadened to include neoliberal-era macroeconomic theory, which characterized the macroeconomy as a dynamic stochastic general equilibrium (DSGE) subject to technology and preference shocks, price rigidities, and transaction costs (Woodford 2003). Large discontinuous ruptures (crises) were ruled out by the strong assumptions made about agents' forward-looking rationality. The DSGE model had seemed an apt fit with the 'great moderation' (Stock and Watson 2002) of the 1990s.

Disagreements among economists broke into the open. Some critiques appeared in economics journals. For example, Kirman (2010) wrote: 'the onset of the crisis is a story of contagion, interdependence, interaction, networks, and trust. Yet, as I have observed, these notions are not features of modern macroeconomic models.' Chicago's Mulligan (2009) and Cochrane (2009a) defended DSGE macro theory, while Barbera (2010) and Da Silva (2010) attacked it, as did Brad DeLong in numerous blog posts. Paul Krugman (2009) referred to the DSGE model as the culmination of a 'Dark Age' in economics in a lengthy New York Times article, drawing a steamy rebuttal from Cochrane (2009b) and Mulligan (2010). Joseph Stiglitz authored critiques in both popular (2008) and academic (2011a; 2011b) outlets.

\section{ECONOMISTS' LINKAGES AND DISJUNCTURES AND THE SUBPRIME CRISIS}

Numerous indictments of economics have appeared in the popular press. These typically contrast the inept thinking of 'insider' economists with that of an unappreciated 'outsider. ${ }^{15}$ Notably, Fox (2009) summarized the evolution of efficient-financial market theory, emphasizing its dependence on informational and competitive conditions attained only in rarefied theoretical settings. In another important volume, Cassidy (2009) argued that the subprime crisis arose in part because the practitioners of 'utopian economics' dominated policy discourse and graduate training. Proponents of this view, who regard markets as invariably fair and efficient, shoved aside 'reality-based economics, which understands that markets do not price in spillovers, are inhabited by less than fully rational decisionmakers, and are prone to panic and excessively conformist herd behavior. Cassidy calls for the ascendancy of 'reality-based' economists who study perceptual problems and behavioral anomalies, and thus can work out how under-regulated markets subject to these problems can experience meltdowns. Cassidy's hope is that 'reality-based' economists in the mould of (heterodox) Hyman Minsky and (neoclassical) Ronald Coase, their prestige boosted after a crisis linked to utopian views, would come to steer theory and policy development in economics.

There were economists who fit Cassidy's mold. Minsky had warned of the coming of 'money-manager capitalism' (Minsky 1996) before his death in 1996. When the

14. Also see Maskin (2010). The 'Bibliography of the Global Financial / Economic Crisis,' compiled by Thomas Bourke for the European University Institute, had reached 32 pages by December 2011.

15. See Lewis $(2010 ; 2011)$ and Morgenstern and Rosner (2011). 
subprime crisis came, Wray (2007) and others elaborated Minskyian analyses of events. As James Galbraith (2009) notes, a number of heterodox economists foresaw the housing market meltdown. In turn, Berkeley economists Jaffee and Quigley set out detailed arguments describing market failures in housing and subprime credit well before the crises in these markets. ${ }^{16}$ As these policy-oriented neoclassical economists saw it, poorly regulated and fee-hungry lenders, interacting with greedy and myopic borrowers seduced by a housing bubble, combined to create unsustainable housing prices and unpayable loans. They laid the emphasis on inadequate regulation, which provided incentives for undue risk-taking. Quigley (2008, p. 2), for example, wrote:

One does not need to invoke the menace of unscrupulous and imprudent lenders or of equally predatory borrowers to explain the rapid collapse of the mortgage market as house price increases slowed in 2006, before ultimately declining. There were certainly enough unscrupulous lenders and predatory borrowers in the market, but the incentives faced by decent people mortgagors and mortgagees - made their behavior much less sensitive to the underlying risks.

In sum, both mainstream and heterodox warnings were in circulation well before the dramatic financial meltdown of September 2008. Why didn't a 'reality-based' perspective emerge as a dominant approach in economics?

There are several reasons. First, Cassidy is not a club member. He holds no academic position, and lacks the standing to get the attention of those in the club. Second, most studies that set out the dire social consequences of subprime lending were generated either by non-academic organizations or by academics who are not members of economics faculties. ${ }^{17}$ In graduate economics programs, virtually no academics remain who work on social aspects of economic processes, on history, or on institutions. That said, even if the latter hold advanced economics degrees, the associational and professional distance separating them will almost certainly be stronger than their shared interest.

This last point goes doubly even for heterodox economists in universities, researching the same issues: in all likelihood, these economists and their neoclassical counterparts work in different departments, share their work in different forums, and are connected to very different non-academic organizations and researchers. Given the realpolitik of money flows for economic research and think-tanks, neoclassical economists are far more likely to be aware of the work of economists espousing neoliberal than heterodox ideas. That is, Cassidy's map of economic ideas does not take into account the power relations and lines of communication within the academic discipline.

Finally, even while Jaffee and Quigley were advancing their views, they were already being aggressively countered by analyses blaming the subprime crisis on governmental interference in (rather than underregulation of) housing credit markets. Most notable here are the sustained efforts of two members of the Shadow Financial Regulatory Committee, Wallison and Calomiris. In 2008, Calomiris argued vis-à-vis the subprime crisis that 'government financial subsidies for bearing risk seem to have been key triggering factors, along with accommodative monetary policy' (2008, p. 1). In October 2009, Calomiris (2009a) argued that contemporary banking crises

16. See Jaffee (2008), Jaffee and Quigley (2006, 2008, and 2010 (originally circulated in 2007)).

17. The leading studies of subprime lending were done outside academic departments of economics; they were conducted by government agencies (US HUD 2000), community-based organizations (CRC 2002, CRC et al. 2008), and academic researchers in fields other than economics (Wyly et al. 2008). 
could be attributed to bank regulators' 'risk-inviting rules'; and he argued in another 2009 essay that 'large, complex financial institutions' (Calomiris 2009b) - that is, the banks often termed 'too big to fail' - are growth-enhancing and efficiency-creating, not problematic. Wallison, in turn, has asserted that the Community Reinvestment Act forced banks into both making home loans to lower-income borrowers and buying subprime loans (Wallison 2009). He has also argued (Wallison 2008) that FNMA and FHLMC purchased excessively risky subprime loans because they enjoyed (and abused) federal protection.

These assertions - that the Community Reinvestment Act and the two governmentsponsored enterprises, Fannie Mae and Freddie Mac, were at the root of the problem are demonstrably false. ${ }^{18}$ Fannie Mae and Freddie Mac did not underwrite subprime loans, and the CRA did not mandate subprime lending. Its principal requirements are that banks meet credit needs in the entirety of their market areas, and do not determine their market-area boundaries in a discriminatory manner.

This brings us to the notion that the subprime crisis was caused by bad regulation: 'risk-inviting' rules (Calomiris) or inattention to perverse incentives (Quigley). This assertion is also inaccurate. Efforts were made to clamp down on subprime lending in its very early stages: in 1994, President Clinton signed the Home Ownership and Equity Protection Act. However, the Federal Reserve did not promulgate regulations implementing this law until July 2008. Alan Greenspan, in particular, argued that the market was efficiently pricing risk as late as 2005 (Hirsch 2008). Several states (including North Carolina in 1999 and New York State in 2002) passed laws regulating predatory lending, but the courts blocked them on the basis that they constituted unfair restraints on trade. Meanwhile, Congress facilitated the highly leveraged speculation in subprime-linked derivatives when it passed (and President Clinton signed) the Commodities Futures Modernization Act of 2000 (Lewis 2010). While these actions, which opened the door to the 2008 crash, were being debated, the Shadow Financial Regulatory Committee registered its support of the 2000 Act and its opposition to any restraints on subprime lending. ${ }^{19}$

In any case, the notion that a flaw in regulation or a distortion in credit markets might lie at the root of the subprime meltdown was an invitation to business as usual. The subprime crisis could be interpreted by both pro-market and pro-intervention contributors to neoclassical economics as constituting not an indictment of the enterprise as a whole, but instead as renewing the set of topics that well-constructed rational-choice models are needed to address. The focus on the use of mechanism designs to rein in market-based risk, in the midst of twin crises demonstrating how risk-based markets can implode, shows the strong pull of the neoclassical sink on neoclassical economists. Phelps (2009, p. 9) warned of the consequences of mechanism-based thinking, in an article criticizing efforts to bound financial risk-taking by compensation reforms: 'this sort of theorizing, though well-intentioned and even useful in exposing the perils of excessive gearing of pay to crude measures of performance, is itself dangerous in leaving the impression that, after reforming bonuses, asset markets will no longer be susceptible to huge asset price swings that are driven only by "speculative excesses" ...'

18. The disregard for the historical and institutional record in the elaboration of these ideas has led journalist Joe Nocera (2011) to call this 'The Big Lie.'

19. See, respectively, Shadow Regulatory Financial Committee (SFRC) Statement No. 163, issued on September 25, 2000, and SFRC Statement No. 173, issued on December 3, 2001. 


\section{GOVERNMENT ON TRIAL: EUROZONE CRISIS}

As we have seen, Wallison and Calomiris responded to the idea that under-regulated markets had malfunctioned with an aggressive counter-argument asserting government failure: governmental attempts to influence market allocations had distorted market forces and led them into unsustainable dynamics. This attack, distorted facts or not, was effective. The shift in analytical attention from perverse market mechanisms to failed, non-credible governmental policies gathered momentum when the subprime crisis jumped the Atlantic Ocean.

This 'jump' occurred in 2009 and 2010, as the effects of the US subprime crisis exposed structural problems in the eurozone - especially, overextended banking sectors and a homegrown housing bubble in several European nations. Then southern-tier governments' incapacity to manage their debt, and the absence of a central bank with a lender-of-last-resort mandate, combined with creditor countries' desires to protect their banks' balance sheets, led to a full-blown eurozone crisis.

The link between the subprime and macro-stagnation crises in the US and the eurozone crisis is evidently government failure. The US subprime crisis and financial meltdown clearly pointed to regulatory failure; its monetary-policy interventions could not prevent stagnant lending and investment; and fiscal stimulus led first to a huge increase in national debt, followed by an anemic recovery only after a huge lag. In Europe, the absence of a well-defined crisis-response role for the European Central Bank imposed employment and output losses on Europe, and inadequate financial regulation led to liquidity starvation and credit freezing in European banking. This last breakdown could be (and has been) attributed to eurozone nations' lack of credibility in formulating plans for debt/GDP reduction. Evidently, then, the unifying thematic in the spread of crisis across the Atlantic is sovereign nations' over-indebtedness, at levels that threaten to become unsustainable.

As with the subprime crisis in the US, heterodox economists have used Keynesian and Marxian insights as well as stratification theory to develop analyses of and policy responses to the European crisis. Authors including Hein and Stockhammer (2010), Papadimitriou and Wray (2011), and Varoufakis (2011) have initiated robust debates about whether the eurozone's design and political constraints will permit the pursuit of sufficiently Keynesian stimulus policies to resolve its crisis, and whether the banking crisis that underlies the eurozone crisis can be reined in. We do not pursue these themes, except to note that Keynesian and Kaleckian analyses that highlight the roles of aggregate-demand adequacy, power, and uncertainty and financial fragility in the eurozone crisis - as well as the impacts of the eurozone crisis on racial and gender inequality - are outside the neoclassical frame of analysis. For this reason, and due to the asymmetric lines of communication been neoclassical and heterodox economists, these analyses have not been taken up in neoclassical discussions of the crisis.

But there has been another factor at play in this second phase of the global crisis. The hardwiring of the eurozone already embodies a neoclassical approach to a national federation. Neoclassical premises in an extreme form - maximum scope for markets and restrictions on governments' freedom of action - define the structure of the eurozone. So the neoclassical position here involves a defence of a governance structure, forcing its critics to argue against one form of governance and for another, a more formidable task than pointing out the consequences of the absence of governance (as in the subprime crisis).

Note that the design of the eurozone conforms rather precisely to the neoclassical rules for theorizing institutions (summarized in Section 2). Every member nation can 
be understood as having a collective endowment, a set of preferences over present and future consumption and leisure, and a given state of technology. If the global economy is understood as a set of nations, each nation can be understood as choosing a consumption/production strategy that maximizes its welfare, given its wealth constraints. The eurozone represents a coalition that can improve member states' welfare by reducing transaction and information costs; its trade and investment mechanisms in no way permit a select number of nation states to live beyond their means.

Limitations of space prevent a full exploration here of the intellectual origins of the eurozone; instead we touch on the visions of this federation in Mundell's work and in the Delors Commission report. ${ }^{20}$ Robert Mundell, the 'father of the eurozone' (Vane and Mulhearn 2006, pp. 99-100), regards his 1963 paper, which introduces the currency union model on which the eurozone was based, as 'the locus classicus of my half of the Mundell-Fleming model' (Mundell 2001, pp. 222-223); its assumptions of perfect capital mobility and of the perfect substitutability of all securities exemplify his point. In Mundell's own words, 'my approach came through a Walrasian-like general equilibrium theory' (Mundell 2001, p. 217). Mundell's locus classicus is clear in his emphasis on bringing 'supply conditions' - 'whether or not firms are prevented from maximizing profits and whether or not workers are impeded in their pursuit of maximum utility' (Mundell 1964, p. 301) into the Keynesian framework that provided the lingua franca of macroeconomics in the 1960s.

The Delors Commission report (1989), in turn - which gave the common currency its definitive thrust forward - embodied a neoclassical view. It argued that the union should encompass 'a large degree of freedom for market behavior' (p. 17): 'Financial markets, consumers and investors would ... penalize deviations from commonly agreed budgetary guidelines or wage settlements, and thus exert pressure for sounder policies.' In addition, member nations would 'have to accept that sharing a common market and a single currency area imposed policy constraints' (ibid., p. 20). Installing an independent central bank and establishing 'the full liberalization of capital movements and financial market integration' (ibid., p. 16) before exchange rates are fixed would make it feasible to coordinate monetary policy across all banks and the entirety of the euro area. So, as in Mundell (1963), making capital completely mobile would lead to welfare-improving equilibria.

This view - the 'voluntary' character of eurozone creation, followed by 'policy constraints' - hides the power relations that are present in eurozone interactions: the effort to cut back the European welfare state, and attacks on labor standards in Europe, to cite just two. As Palast (2012) observed, this constitutes the fulfilment of the plan, not its negation. Indeed, the fact that it was created in part as an attractive trading and investment partner for globally mobile financial and production capital already illustrates the centrality of power in the eurozone's creation. The framing of the eurozone crisis, then as in the subprime crisis - involves the double invisibility of power.

In sum, as a neoliberal mechanism design established using neo-Walrasian logic, the eurozone's limits on its member nations' policy choices seem necessary, even natural. Keynesian and Kaleckian analysts have for years pointed out the design flaws inherent in the eurozone mechanism. ${ }^{21}$ The principal flaws they indicated were the restriction on national fiscal policy, the limits on fiscal adjustments in the event of a downturn, and the limited role given to the European Central Bank. These flaws,

20. Dymski (2013b) explores the intellectual roots of the eurozone, in particular by contrasting the views of Fleming and Mundell.

21. See, for example, Arestis et al. (1999; 2001). 
which are obvious from a Keynesian perspective, largely disappear under Neoclassical assumptions. As briefly noted, contemporary heterodox writing on the eurozone crisis has, if anything, sharpened these critiques. But the same factors explaining the muted neoclassical response to the subprime crisis are present here. First, few channels exist whereby Keynesian/Kaleckian critiques of eurozone design could affect neoclassical discussions about how to modify this design. ${ }^{22}$ Second, the economists making modifications to eurozone rules have little interest in the social (much less political) consequences of their decisions. The austerity policies adopted by countries that have exceeded eurozone debt-limit rules are viewed (as in the Latin American and East Asian crises of earlier decades) as purely technical fixes, despite evidence that austerity policies have profound distributional consequences (Callan et al. 2011). Third, the eurozone's design, as noted, invites policy discussions and theoretical analysis that stay within the Walrasian intellectual sink, discouraging inquiry that might shift onto the heterodox themes of power, inequality, uncertainty, and aggregate-demand insufficiency.

\section{CONCLUSION: THE HETERODOX SPIRAL AFTER THE TWIN CRISES}

The neoliberal principles that guided economic policy in the past 30 years hypothesized that power in markets is irrelevant, because global competition disciplines all market participants; that social impacts of market processes are not the concern of economists; that uncertainty has become irrelevant due to advances in computational power; and that aggregate demand is always available to absorb any efficiently-produced supply. That is, all the defining features in heterodox approaches to economics were judged to be irrelevant in neoliberal-era governance. While the subprime crisis showed that each of these principles was misguided, neoclassical economists remain unwilling to replace the Walrasian general equilibrium as their fundamental reference point. The same limitation is evident in economists' reaction to the eurozone crisis: the core question for analysts working from neoclassical premises is how to adjust the rules so that Europe can return to the long-term, stable growth path from which it was pulled due to short-sighted, undisciplined member states.

The neoclassical sink plays a continuing role as an intellectual basis for post-crisis policy debate in large part because neoclassical theory has remained a vital reference point for many economists, even for many of those who have criticized austerity policies. One evidence of this is that the DSGE model has not been discarded. On the contrary, as Ascari (2011, pp. 19-20) recently put it in a forum on the future of macroeconomics:

The future in my view is neither to look back nor to waste another 10 years in useless debates about Keynesian versus neoclassical economists. We cannot afford it. We should straight away follow the path of developing and improving macroeconomics, and build up a New-New NeoClassical Synthesis. Let us proceed and incorporate features in DSGE models that are not there at the moment. Actually, the movement already started some time ago ... We have models with financial frictions and banking and, as I said, many more are to come. ... [A]t the moment it is still difficult to put them into a fully fledged DSGE model. But sooner rather than later that will be possible.

22. Consider the tepid and belated response to the 'modest proposal' of Varoufakis and Holland (2011). 
Miller (2011, p. 23) disagrees with Ascari in his contribution to this forum, arguing that macroeconomics "will involve acceptance of greater pluralism and an eclectic, problem-oriented approach - less like the General Equilibrium theorizing of Debreu and Woodford (we have the answer - what is the problem?) and more like the MIT macroeconomics of Solow and Stiglitz (show us the problem and we will make you a model to analyse it - and maybe offer some policy prescriptions).' Ascari's response (2011, p. 20) to this provocation is telling: 'There is only one way to beat a model you think is bad: write down another model that is better. Simply criticizing it on the basis of a priori arguments is not very constructive.'

An unstated ground rule for this challenge is that this 'better' model must conform with the conventions of the neoclassical sink. This provocation is irresistible to economists skilled in the tools of abstract model-building. There are, after all, infinite solutions to incomplete markets models, and thus an infinite number of sub-optimal equilibria that can be generated by strategically-chosen deviations from the assumptions needed for Walrasian equilibrium - and, in principle, an infinite number of ways in which policy mechanisms or market reforms can improve on these sub-optimal states. This game is already well progressed. Work by Geneakoplos, Brunnemeier, Shin, and Vishny and Shleifer, among others - highlighted by Whitehouse (2009) - uses agent-optimization models to show how financial crises can result from the precipitous emergence of structural demand-supply imbalances in the markets for liquidity and speculative assets. Shiller (2008) proposed (and patented) a new set of housing-price indices as an earlywarning device against future housing-price bubbles. He was among the many financial economists who collaborated on the 'Squam Lake Report' (French et al., 2010), which proposes new market-based approaches to financial risk containment.

Stiglitz (2011a, p. 19) argues that the failure of the 'Standard Model' (DSGE) to predict bubbles, and its inattention to incentives and market failures, suggests refocusing macroeconomics on situations in which 'information is imperfect, and risk markets are incomplete.' In a related essay, Stiglitz (2011b) sets out four hypotheses which can explain why the downturn has been so severe, and the recovery so weak: adverse changes in the economy's risk properties; a deterioration in the quality of financial information, financial-market changes that have adversely affected the efficiency of the credit system, and structural transformation(s). This critique and diagnosis suggest expanded attention to the agent-based asymmetric-information models that Stiglitz himself helped pioneer. Despite his strong critiques of neoliberal policies, Stiglitz is not proposing a unifying framework for heterodox analysis; he is proposing a paradigm shift which largely preserves the line between economic and social theory, but which relocates the ground-zero reference point of economic theory from a market-clearing equilibrium to a non-market-clearing, imperfect information equilibrium (Stiglitz 1988; 1999; 2002). In the context of this argument, Stiglitz's ambition as an economic theorist is to save neoclassical theory by transforming it. ${ }^{23}$ Marx, Folbre, and most of Keynes would, vis-à-vis this reconstituted discipline, remain on the outside looking in.

For economists committed to heterodox ideas - for whom Marx, Folbre, and Keynes are central reference points - the outbreak of the twin crises was far less of

23. Stiglitz (2011a, pp. 28-29) describes his approach as follows: 'When I was an undergraduate student beginning my study of economics, ... it seemed I was born just a little bit too late: all the great ideas had already been discovered. Keynesian economics, I thought, was a brilliant idea. I wished I had been around before Keynes so I could have discovered those ideas. But I came to find out that there were some other holes in economic theory that I could spend my time fruitfully working on.' 
a surprise than for neoclassical theorists; and these crises' social and economic costs have been far clearer. Heterodox analysts have, from their various entry points, asserted that the current crisis requires far more than incremental policy adjustment; instead, a pivotal moment in the historical trajectory of advanced capitalism in the global North has arrived.

There is no need to make judgements about which viewpoints are more fundamental than others in the various substrata of heterodox economics - nor does a scientifically or social neutral means of doing so exist. There is no single intellectual sink that serves as an attractor or a point of reference for all the viewpoints that arise in heterodox economics. Nor is there a single social movement which has given rise to all the points of view represented in heterodox thought. At the same time, heterodox ideas for reformulating economic theory and policy after the twin crises must cross-pollinate if they are to constitute an effective counterpoint to thinking that emanates from the neoclassical sink. To note that heterodox analyses constitute an analytical spiral is to acknowledge their distinct reference points, but also to point up their interconnections. Solving a problem of inadequate aggregate demand, for example, requires that we take on the problem of uncertainty, which can undercut investment and consumption demand. And these same components of demand can be affected adversely, in turn, by the exercise of market power by firms that supply credit, non-renewable resources, consumer goods to the public, and so on.

Economists committed to heterodox premises have both the opportunity to deepen insights derived from whatever entry point they build on (power, uncertainty, gender or racial inequality, and so on) and the responsibility to consider how their work connects with other points along the heterodox spiral. The challenge facing the heterodox in economics is to embrace a multi-centric paradigm of difference, not to substitute a new intellectual sink for the neoclassical sink that years of orthodox theorizing have put into place.

\section{REFERENCES}

Arestis, Philip, Andrew Brown, and Malcolm Sawyer (2001), The Euro: Evolution and Prospects, Cheltenham, UK: Edward Elgar.

Arestis, Philip, Kevin McCauley, and Malcolm Sawyer (1999), 'An Alternative Stability Pact for the European Union,' Working Paper No. 296, Annandale-on-Hudson, NY: Levy Economics Institute, October.

Arrow, Kenneth (2008), 'Risky Business,' The Guardian, online 'Comment is free' section, October 15. Accessed on December 22, 2011 at http://www.guardian.co.uk/commentisfree/ cifamerica/2008/oct/15/kenneth-arrow-economy-crisis.

Ascari, Guido (2011), 'Macroeconomic Models: Better Horses for Tougher Courses,' The Manchester School, Supplement, pp. 17-20.

Baker, Dean (2007), 'Midsummer Meltdown Prospects for the Stock and Housing Markets,' Washington, DC: Center for Economic and Policy Research, August.

Barbera, Robert J. (2010), 'If There Were a Fight, They Would Have Stopped it in November 2008,' (comment on Mulligan), The Economists' Voice, April.

Callan, Tim, Chrysa Leventi, Horacio Levy, Manos Matsaganis, Alari Paulus, and Holly Sutherland (2011), 'The Distribution Effects of Austerity Measures: A Comparison of Six EU Countries,' Brussels: Directorate-General for Employment, Social Affairs, and Equal Opportunities, European Commission, November.

Calomiris, Charles W. (2007), 'Not (Yet) a "Minsky Moment",' American Enterprise Institute website. Accessed on December 11 at http://www.aei.org/docLib/20071010_Not(Yet) AMinskyMoment.pdf. 
Calomiris, Charles W. (2008), 'The Subprime Turmoil: What's Old, What's New, and What's Next,' Vox website, August 22. Accessed at http://www.voxeu.org/article/subprime-turmoilwhat-s-old-what-s-new-and-what-s-next?.

Calomiris, Charles W. (2009a), 'Banking Crises and the Rules of the Game,' NBER Working Paper 15403, Cambridge, MA: National Bureau of Economic Research, October.

Calomiris, Charles W. (2009b), 'In the World of Banks, Bigger can be Better,' Wall Street Journal, October 20.

Cassidy, John (2009), How Markets Fail: The Logic of Economic Calamities, New York: Farrar, Straus and Giroux.

Cochrane, John (2009a), 'Fiscal Stimulus, Fiscal Inflation, or Fiscal Fallacies,' mimeo, University of Chicago Booth School of Business, February 27.

Cochrane, John (2009b), 'How did Paul Krugman get it so Wrong?', Booth Business School, University of Chicago, mimeo, September 16.

Colander, David, Ric Holt, and J. Barkley Rosser (2004), 'The Changing Face of Mainstream Economics,' Review of Political Economy, 16(4), 485-499.

Delors Commission (1989), Jacques Delors, Chairman, Committee for the Study of Economic and Monetary Union Report on Economic and Monetary Union in the European Community, Brussels: European Community, April 17.

CRC (California Reinvestment Coalition) (2002), Inequities in California's Subprime Mortgage Market, San Francisco: California Research Coalition, November.

CRC (California Reinvestment Coalition), Community Reinvestment Association of North Carolina, Empire Justice Center, Massachusetts Affordable Housing Alliance, Neighborhood Economic Development Advocacy Project, Ohio Fair Lending Coalition and Woodstock Institute (2008), Paying More for the American Dream: The Subprime Shakeout and its Impact on Lower-Income and Minority Communities, San Francisco: California Reinvestment Coalition.

Da Silva, Sergio (2010), 'Comment on Mulligan: Keynes in both Fresh and Salt Water,' The Economists' Voice, April.

De Vroey, Michel (1975), 'The Transition from Classical to Neoclassical Economics: A Scientific Revolution,' Journal of Economic Issues, 9(3), 415-439.

Diamond, Douglas (1984), 'Financial Intermediation as Delegated Monitoring,' Review of Economic Studies, 51, 393-414.

Downs, Anthony (2007), 'Credit Crisis: The Sky is not Falling,' Policy Brief No. 164, Economic Studies, The Brookings Institution, October 31.

Dymski, Gary A. (2011), 'Limits of Policy Intervention in a World of Neoliberal Mechanism Designs: Paradoxes of the Global Crisis,' Panoeconomicus, 58(3), 285-308.

Dymski, Gary A. (2013a), 'The Neoclassical Sink and the Heterodox Spiral: Why the Twin Global Crisis has not Transformed Economics,' in G.C. Harcourt and Peter Kreisler (Eds), Oxford Handbook of Post-Keynesian Economics, Vol. 2: Critiques and Methodology, Oxford: Oxford University Press, pp. 436-457.

Dymski, Gary A. (2013b), 'The Eurozone Crisis as a Trilemma Forcefield: Fleming, Mundell, and Power in Finance,' mimeo, Leeds University Business School, August.

Fama, Eugene (1980), 'Banking in the Theory of Finance,' Journal of Monetary Economics, 6(1), 39-57.

Fender, Ingo and Janet Mitchell (2005), 'Structured Finance: Complexity, Risk and the Use of Ratings,' BIS Quarterly Review, June, 67-87.

Fox, Justin (2009), The Myth of the Rational Market: A History of Risk, Reward, and Delusion on Wall Street, New York: Harper Business.

French, Kenneth R., Martin N. Baily, John Y. Campbell, John H. Cochrane, Douglas W. Diamond, Darrell Duffie, Anil K. Kashyap, Frederic S. Mishkin, Raghuram G. Rajan, David S. Scharfstein, Robert J. Shiller, Hyun Song Shin, Matthew J. Slaughter, Jeremy C. Stein, and Rene M. Stulz (2010), The Squam Lake Report: Fixing the Financial System, Princeton: Princeton University Press.

Galbraith, James K. (2009), 'Who are these Economists, Anyway?', Thought and Action: The NEA Education Journal, Fall, 85-98. 
Harcourt, Geoffrey C. (1982), 'Conclusion: The Social Science Imperialists,' in G.C. Harcourt, edited by Prue Kerr, The Social Science Imperialists, London: Routledge and Kegan Paul, pp. 377-393.

Harcourt, Geoffrey C. (2007), 'The Theoretical and Political Importance of the Economics of Keynes: or, What Would Marx and Keynes have Made of the Happenings of the Past 30 Years and More?', in Mathew Forstater, Gary Mongiovi, and Stephen Pressman (Eds), Post Keynesian Macroeconomics: Essays in Honour of Ingrid Rima, New York: Routledge, pp. 56-69.

Harcourt, Geoffrey C. (2010), 'The Crisis in Mainstream Economics,' Real-World Economics Review, 53, 47-52. Available at http://www.paecon.net/PAEReview/.

Harcourt, Geoffrey C. and H.P. Nolan (2009), 'Price Theory and Multinational Oligopoly: Kurt Rothschild and Stephen Hymer Revisisted,' in Manoj Kumar Sanyal, Mandira Sanyai, and Shahina Amin (Eds), Post-Reform Development in Asia: Essays for A.K. Bagchi, Hyderabad: Orient Blackswan, pp. 263-288.

Hein, Eckhard and Engelbert Stockhammer (2010), 'Macroeconomic Policy Mix, Employment and Inflation in a Post-Keynesian Alternative to the New Consensus Model,' Review of Political Economy, 22, 317-354.

Hirsch, Michael (2008), 'Greenspan's Folly,' Newsweek, September 16.

Hymer, Steven H. (1972), 'The Multinational Corporation and the Law of Uneven Development,' in Jagdish N. Bhagwati (Ed.), Economics and World Order, London: Macmillan, pp. 113-140.

Jaffee, Dwight M. (2008), 'Regulating the Investment Banks and GSEs After the Subprime Crisis,' Fisher Center Working Papers, University of California, Berkeley, October.

Jaffee, Dwight M., and John M. Quigley (2006), 'Housing Subsidies and Homeowners: What Role for Government-Sponsored Enterprises?', Brookings Papers on Urban Affairs, 6(1), $103-150$.

Jaffee, Dwight M. and John M. Quigley (2008), 'Mortgage Guarantee Programs and the Subprime Crisis,' Working Paper No. W08-006, Program on Housing and Urban Policy, University of California, Berkeley, August.

Jaffee, Dwight M. and John M. Quigley (2010), 'Housing Policy, Subprime Mortgage Policy, and the Federal Housing Administration,' in Deborah Lucas (Ed.), Measuring and Managing Federal Financial Risk, Cambridge, MA: National Bureau of Economic Research, pp. 97-125.

Kaufman, Henry (2007), 'Our Risky New Financial Markets,' The Wall Street Journal, August 15.

Kirman, Alan (2010), 'The Economic Crisis is a Crisis for Economic Theory,' CESifo Economic Studies, 56(4), 498-535.

Krugman, Paul (2007a), 'Gone Baby Gone,' New York Times, October 22.

Krugman, Paul (2007b), 'Banks Gone Wild,' New York Times, November 23.

Krugman, Paul (2009), 'How did Economists get it so Wrong?', New York Times (Sunday Magazine), September 6.

Levitt, Steven D. and Stephen J. Dubner (2005), Freakonomics: A Rogue Economist Explains the Hidden Side of Everything, New York: William Morrow.

Lewis, Michael (2010), The Big Short: Inside the Doomsday Machine, New York: W.W. Norton.

Lewis, Michael (2011), Boomerang: Travels in the New Third World, New York: W.W. Norton.

Maskin, Eric (2010), 'Eric Maskin on Economic Theory and Financial Crisis,' interview by Sophie Roel, July 4. Accessed on December 22, 2011 at http://thebrowser.com/interviews/ eric-maskin-on-economic-theory-and-financial-crisis.

Meltzer, Allen (2007), 'Let 'em Fail,' Wall Street Journal, July 21, A6.

Miller, Marcus (2011), 'Macroeconomics: A Discipline not a Science,' The Manchester School, Supplement, 21-24.

Minsky, Hyman (1996), 'Uncertainty and the Institutional Structure of Capitalist Economies,' Journal of Economic Issues, 30(2), 357-368.

Morgenstern, Gretchen and Joshua Rosner (2011), Reckless Endangerment: How Outsized Ambition, Greed, and Corruption led to Economic Armageddon, New York: Times Books.

Mulligan, Casey B. (2009), 'Is Macroeconomics Off-Track?', The Economists' Voice, November. 
Mulligan, Casey B. (2010), 'Aggregate Implications of Labor Market Distortions: The Recession of 2008-09 and Beyond,' NBER Working Paper No. 15681, Cambridge, MA: National Bureau of Economic Research, January.

Mundell, Robert A. (1963), 'Capital Mobility and Stabilization Policy under Fixed and Flexible Exchange Rates,' Canadian Journal of Economic and Political Science, 29(4), 475-485.

Mundell, Robert A. (1964), 'An Exposition of Some Subtleties in the Keynesian System,' Weltwirtschaftliches Archiv, Bd. 93, 301-313.

Mundell, Robert A. (2001), 'On the History of the Mundell-Fleming Model,' IMF Staff Papers, 47 (Special issue), 215-228.

Nocera, Joe (2011), 'The Big Lie,' New York Times, December 23.

Oldfield, George S. (2000), 'Making Markets for Structured Mortgage Derivatives,' Journal of Financial Economics, 57, 445-471.

Palast, Gregory (2012), 'Robert Mundell, Evil Genius of the Euro,' The Guardian, June 26.

Palley, Thomas I. (2007), 'Financialization: What it is and Why it Matters,' Working Paper No. 525, Annandale-on-Hudson, NY: Levy Economics Institute of Bard College, December.

Papadimitriou, Dmitri and L. Randall Wray (2011), 'Euroland in Crisis as the Global Meltdown Picks Up Speed,' Working Paper No. 693, Annandale-on-Hudson, NY: Levy Economics Institute of Bard College, October.

Phelps, Edmund S. (2009), 'Refounding Capitalism,' Capitalism and Society, 4(3), 1-12.

Pollock, Alex (2007), 'Subprime Bust Expands,' mimeo, American Enterprise Institute, The American - A Magazine of Ideas, August 6. Accessed on December 11 at american.com, http://american.com/archive/2007/august-0807/subprime-bust-expands.

Quigley, John M. (2008), 'Compensation and Incentives in the Mortgage Business,' Economists' Voice, 5(6), 1-3.

Rothschild, Kurt (1947), 'Price Theory and Oligopoly,' Economic Journal, 57, 299-320.

Roubini, Nouriel (2007), 'Are we at the Peak of a Minsky Credit Cycle?', blog entry, July 30. Accessed at http://www.economonitor.com/nouriel/2007/07/30/are-we-at-the-peak-of-aminsky-credit-cycle/.

Shiller, Robert J. (2005), Irrational Exuberance, 2nd Edn, Princeton: Princeton University Press.

Shiller, Robert J. (2008), 'Derivatives Markets for Home Prices,' NBER Working Paper 13962, Cambridge, MA: National Bureau of Economic Research, April.

Stiglitz, Joseph E. (1988), 'Why Financial Structure Matters,' Journal of Economic Perspectives, 2(4), 121-126.

Stiglitz, Joseph E. (1999), 'Toward a General Theory of Wage and Price Rigidities and Economic Fluctuations,' American Economic Review, 89(2), 75-81.

Stiglitz, Joseph E. (2002), 'Information and the Change in Paradigm in Economics,' American Economic Review, 92(3), 460-505.

Stiglitz, Joseph E. (2008), 'Capitalist Fools,' Vanity Fair, December 12.

Stiglitz, Joseph E. (2011a), 'Rethinking Macroeconomics: What Failed, and How to Repair it,' Journal of the European Economic Association, 9(4), 591-645.

Stiglitz, Joseph E. (2011b), 'The Failure of Macroeconomics in America,' China and the World Economy, 19(5), 17-30.

Stock, James H. and Mark W. Watson (2002), 'Has the Business Cycle Changed and Why?', in Mark Gertler and Kenneth Rogoff (Eds), NBER Macroeconomics Annual 2002, Volume 17, Cambridge, MA: MIT Press, pp. 159-218.

US HUD (US Department of Housing and Urban Development) (2000), Unequal Burden: Income and Racial Disparities in Subprime Lending in America, Washington, DC: Department of Housing and Urban Development, April.

Vane, Howard R. and Chris Mulhearn (2006), 'Interview with Robert A. Mundell,' Journal of Economic Perspectives, 20(4), 89-110.

Varoufakis, Yanis (2011), The Global Minotaur, London: Zed Books.

Varoufakis, Yanis and Stuart Holland (2011), 'A Modest Proposal for Overcoming the Euro Crisis,' Policy Note, 2011/3, Annandale-on-Hudson, NY: Levy Economics Institute of Bard College. 
Vernengo, Mattias (2010), 'Conversation or Monologue? On Advising Heterodox Economists,' Journal of Post Keynesian Economics, 32(3), 389-396.

Wallison, Peter J. (2008), 'Cause and Effect: Government Policies and the Financial Crisis,' AEI Outlook Series, Washington, DC: American Enterprise Institute, November.

Wallison, Peter J. (2009), 'The True Origins of this Financial Crisis,' American Spectator, February.

Whitehouse, Mark (2009), 'Crisis Compels Economists to Reach for New Paradigm,' Wall Street Journal, November 4, A1.

Woodford, Michael (2003), Interest and Prices: Foundations for a Theory of Monetary Policy, Princeton: Princeton University Press.

Wray, L. Randall (2007), 'Lessons from the Subprime Meltdown,' Working paper no. 522, Levy Economics Institute of Bard College, December.

Wyly, Elvin, Markus Moos, Holly Foxcroft, and Emmanuel Kabahizi (2008), 'Subprime Mortgage Segmentation in the American Urban System,' Tijdschrift voor Economische en Sociale Geografie, 99(1), 3-23. 